\title{
STRATEGI PENGEMBANGAN DESA WISATA DI KECAMATAN KARANGPLOSO KABUPATEN MALANG
}

\author{
Selamet Joko Utomo, Bondan Satriawan \\ Prodi Ekonomi Pembangunan Universitas Trunojoyo Madura \\ Email: sjutomo@trunojoyo.ac.id
}

\begin{abstract}
ABSTRAK
Tujuan penelitian ini adalah untuk sebagai upaya untuk merumuskan rencana strategis pengembangan desa wisata di Kecamatan Karangploso yang berbasis pada keunikan dan sektor unggulan lokal (pertanian, peternakan, jasa dll) serta melalui pendekatan partisipatif.Teknik analisis data yang digunakan dalam penelitian ini adalah teknik analisis data kualitatif. Pada tahap perumusan strategi pembentukan desa wisata di Desa Tawangargo dan Desa Donowarih Kecamatan Karangploso, peneliti menggunakan teknik analisis SWOT. Hasil analisis menunjukkan Kecamatan Karangploso memiliki potensi internal dan eksternal pariwisata yang dapat dikembangkan menjadi desa wisata. Strategi yang digunakan berupa klaster pengembangan desa wisata, lembaga desa wisata dan pengembangan desa wisata dengan tema Desa wisata berperspektif go green yang unik, khas dan sehat yang berbasis pada keunggulan hortikultura.
\end{abstract}

Kata kunci: Strategi, Desa, Wisata, SWOT

\section{LATAR BELAKANG}

Kabupaten Malang merupakan salah satu kabupaten terluas di Propinsi Jawa Timur, dengan luas wilayah $3.348 \mathrm{~km}^{2}$ atau sama dengan 334.800 ha. Secara demografis kabupaten Malang memiliki jumlah penduduk sebesar 2.346.710 jiwa dan merupakan terbesar kedua setelah Kotamadya Surabaya. Mengingat bahwa potensi alam dan budaya yang khas tersebut tersebar hampir di sebagian besar wilayah kabupaten Malang, maka besar kemungkinan untuk dikembangkan konsep desa wisata (village torurism). Konsep Desa Wisata Dinas Kebudayaan dan Pariwisata Kabupaten Malang merupakan suatu wilayah pedesaan yang memiliki potensi keunikan dan daya tarik wisata yang khas,

Kriteria suatu desa dapat dikembangan menjadi desa wisata, apabila memiliki beberapa faktor-faktor pendukung antara lain; (1) Memiliki potensi produk dan daya tarik, (2) memiliki dukungan sumber daya manusia (SDM), (3) motivasi kuat dari masyarakat, (4) memiliki dukungan sarana dan prasarana yang memadai, (5) mempunyai fasilitas pendukung kegiatan wisata, (6) mempunyai kelembagaan yang mengatur kegiatan wisata, dan (7) ketersediaan lahan/area yang dimungkinkan untuk dikembangkan menjadi tujuan wisata.

Mengacu pada kriteria pengembangan desa wisata di atas, maka desa Tawangargo dan Donowarih merupakan desa di kecamatan Karangploso Kabupaten Malang yang berpotensi untuk dikembangkan menjadi desa wisata. 
Desa Tawangargo, desa Bocek dan desa Donowarih merupakan desa yang kultur agrarisnya masih terlihat kental, terbukti bahwa desa Tawangargo dan Donowarih adalah sentra penanaman hortikultura terutama sayur mayur terbesar keempat di Malang Raya. Sedangkan desa Bocek merupakan sentra penanaman cabe besar selain kecamatan Pujon dan Kecamatan Dau. Di kecamatan Karangploso juga terdapat Rumah Pintar yang merupakan sarana yang lengkap untuk mendapatkan aneka informasi terutama untuk anak-anak dan remaja usia sekolah.

Berdasarkan pada karakteristik dan potensi wilayahnya, maka desa Tawangargo dan Donowarih Kecamatan Karangploso merupakan desa yang memungkinkan untuk dikembangkan menjadi obyek kajian desa wisata (village tourism). Tujuan dari Kajian Pembentukan Desa Wisata(village tourisme)di Kecamatan Karangploso Kabupaten Malang ini dimaksudkan sebagai upaya untuk merumuskan rencana strategis pengembangan desa wisata yang berbasis pada keunikan dan sektor unggulan lokal (pertanian, peternakan, jasa dll) serta melalui pendekatan partisipatif.

\section{TINJAUAN PUSTAKA \\ Definisi Pariwisata (Tourism)}

Pengertian Pariwisata menurut definisi yang luas adalah perjalanan dari satu tempat ke tempat lain, bersifat sementara, dilakukan perorangan maupun kelompok, sebagai usaha mencari keseimbangan atau keserasian dan kebahagiaan dengan lingkungan hidup dalam dimensi sosial, budaya, alam dan ilmu.(Smith and French, 1994).Definisi desa pariwisata dapat didekati melalui 4 kategori yaitu:Dimensi Spasial, Dimensi Industri/Bisnis, Dimensi Akademis, Dimensi Sosial Budaya

\section{Definisi Desa Wisata (Village Tourism)}

Desa Wisata (village tourism) menurut Dinas Kebudayaan dan Pariwisata Kabupaten Malang adalah suatu wilayah pedesaan yang memiliki potensi keunikan dan daya tarik wisata yang khas, baik berupa karakter fisik lingkungan alam pedesaan maupun kehidupan sosial budaya kemasyarakatan. (Disbudpar Kab. Malang, 2006).Terdapat dua konsep yang utama dalam komponen desa wisata, yaitu :pertama, Akomodasi adalah sebagian dari tempat tinggal para penduduk setempat dan atau unit-unit yang berkembang atas konsep tempat tinggal penduduk. Kedua, Atraksi adalah seluruh kehidupan keseharian penduduk setempat beserta setting fisik lokasi desa yang memungkinkan berintegrasinya wisatawan sebagai partisipasi aktif.

\section{Pendekatan Pengembangan Desa Wisata}

Berdasar dari penelitian dan studi-studi dari UNDP/WTO dan beberapa konsultan Indonesia, dicapai dua pendekatan dalam menyusun rangka kerja/konsep kerja dari pengembangan sebuah desa menjadi desa wisata, yaitu melalui pendekatan pasar dan pendekatan fisik.Pertama,Pendekatan Pasar untuk Pengembangan Desa Wisata antara lain sebagai berikut ; (1) Interaksi tidak langsung adalah Model pengembangan didekati dengan cara bahwa desa mendapat manfaat tanpa interaksi langsung dengan wisatawan. (2) Interaksi setengah langsung adalah Bentuk-bentuk one day trip yang dilakukan oleh 
wisatawan, kegiatan-kegiatan meliputi makan dan berkegiatan bersama penduduk. (3) Interaksi LangsungWisatawan dimungkinkan untuk tinggal/bermalam dalam akomodasi yang dimiliki oleh desa tersebut. Pada Pendekatan Pasar ini diperlukan beberapa kriteria yaitu : (a) Atraksi wisata; Jarak Tempuh; (b) Besaran Desa; (c) Sistem Kepercayaan dan kemasyarakatan;(d) Ketersediaan infrastruktur.

Kedua, Pendekatan Fisik Pengembangan Desa Wisata dimana pendekatan ini merupakan solusi yang umum dalam mengembangkan sebuah desa melalui sektor pariwisata dengan menggunakan standar-standar khusus dalam mengontrol perkembangan dan menerapkan aktivitas konservasi.

\section{Persyaratan Desa Wisata.}

Merujuk kepada definisi desa wisata, desa-desa yang bisa dikembangkan dalam program desa wisata akan memberikan contoh yang baik bagi desa lainnya, penetapan suatu desa dijadikan sebagai desa wisata harus memenuhi persyaratanpersyaratan, antara lain sebagai berikut :

a. Aksesbilitasnya baik, sehingga mudah dikunjungi wisatawan dengan menggunakan berbagai jenis alat transportasi.

b. Memiliki obyek-obyek menarik berupa alam, seni budaya, legenda, makanan local, dan sebagainya untuk dikembangkan sebagai obyek wisata.

c. Masyarakat dan aparat desanya menerima dan memberikan dukungan yang tinggi terhadap desa wisata serta para wisatawan yang datang ke desanya.

d. Keamanan di desa tersebut terjamin.

e. Tersedia akomodasi, telekomunikasi, dan tenaga kerja yang memadai.

f. Beriklim sejuk atau dingin.

g. Berhubungan dengan obyek wisata lain yang sudah dikenal oleh masyarakat luas.

\section{METODE PENELITIAN}

Penelitian ini merupakan penelitian eksplorasi, di mana akan melakukan ekplorasi terhadap pembentukan desa wisata di Kecamatan Karangploso. Penelitian eksplorasi diartikan oleh (Moleong, 2002) sebagai 'a process of determining whether a social intervention has produced the intended result'. Penelitian ini ditujukan untuk mengetahui potensi dan tantangan dalam pembentukan desa wisata di Kecamatan Karangploso Kabupaten Malang. Penelitian ini dilakukan dengan pendekatan kualitatif dekriptif.

Teknik analisis data yang digunakan dalam penelitian ini adalah teknik analisis data kualitatif. Pada tahap perumusan strategi pembentukan desa wisata di Desa Tawangargo dan Desa Donowarih Kecamatan Karangploso, peneliti menggunakan teknik analisis SWOT, dengan teknik SWOT kita dapat mengetahui kekuatan, kelemahan, ancaman dan peluang dalam pembentukan desa wisata di Desa Tawangargo dan desa Donowarih Kecamatan Karangploso.Selanjutnya untuk merumuskan model desa wisata, peneliti berpijak pada data hasil pemetaan 
potensi dan rumusan strategi tersebut yang dielaborasi menjadi skema konsep yang lebih operasional.

\section{PEMBAHASAN}

\section{Analisis Kondisi Internal}

Mengacu pada konsep desa wisata (village tourism) yang diterbitkan oleh Dinas Kebudayaan dan Pariwisata (Disbudpar) Kabupaten Malang tahun 2006, aspekaspek penting yang harus dimiliki oleh desa wisata adalah sebagai berikut:

\section{Potensi Produk dan Daya Tarik Obyek Wisata}

Mengingat bahwa modal dasar yang harus dimiliki oleh desa wisata adalah adanya obyek wisata sebagai daya tarik wisatawan, berdasarkan pada data potensi bab sebelumnya maka potensi Kecamatan Karangploso yang memiliki daya tarik terhadap wisatawan dan memungkinkan untuk dikembangkan menjadi desa wisata antara lain sebagai berikut;

1. Wisata Religi Gunung Mujur di desa Donowarih

2. Kolam Renang Agro Kencana di Desa Donowarih

3. Komunitas Tradisional di Dusun Borogragal desa Donowarih

4. Rencana Pembangunan Rest Area 2 Ha di Desa Donowarih

5. Kesenian Tradisional Pencak Silat dan Kudalumping sejumlah 4 kelompok di desa Donowarih

6. Wisata Alam Mata Air Umbulan di Desa Donowarih

7. Kesenian Jaranan desa Tawangargo

8. Kesenian Religi Hadrah desa Tawangargo

9. Tempat Area Kemping di dusun Borogondang desa Tawangargo

10. Wisata Alam Sumber Air Sumbersari desa Tawangargo

11. Desa Tawangargo adalah sentra penanaman hortikultura terutama sayur mayur terbesar keempat di Malangraya setelah Kota Batu, Kecamatan Pujon, Kecamatan Poncokusumo dan desa Bocek merupakan sentra penanamancabe besar selain kecamatan Pujon dan Kecamatan Dau

12. Rumah Pintar untuk anak-anak dan remaja usia sekolah

13. Balai Pengkajian Teknologi Pertanian Jawa Timur (BPTP)

14. Balai Penelitian Tanaman Tembakau dan Serat (Balittas)

\section{Dukungan Sumber Daya Manusia (SDM)}

Berdasarkan data monografi desa diketahui bahwa 93,4\% penduduk desa Tawangargo bekerja pada sektor pertanian sebanyak 4.100 orang, yaitu meliputi petani $(22,49 \%)$ dan buruh tani $(70,94 \%)$. Pekerjaan masyarakat yang paling besar adalah buruh tani, hal ini menunjukkan bahwa mereka tidak memiliki lahan sendiri.Sehingga pada saat tidak ada permintaan untuk bekerja, para buruh tani ini melakukan kerja serabutan. Demikian pula dengan desa Donowarih, pekerjaan mayoritas penduduk juga di sektor pertanian, akan tetapi dengan proporsi yang lebih kecil yaitu sebesar 54,33\%. Sebanyak 26,21\% penduduk Donowarih bekerja sebagai petani dan sebesar $28,12 \%$ bekerja sebagai buruh tani.

Apabila dilihat dari aspek pendidikan, maka rata-rata pendidikan masyarakat hanya sampai Sekolah Mengenah Atas (SMA). Di desa Tawangargo 
penduduk yang tidak bersekolah/putus sekolah sebesar 30,94\%, sedangkan keseluruhan masyarakat yang menenpuh pendidikan SD hingga SMA sebesar $66,71 \%$, dimana pendidikan dasar sebesar $32,11 \%$, SMP sebesar $22,59 \%$ dan SMA sebesar $12,01 \%$.

Desa Donowarih juga menunjukkan data pendidikan yang relatif sama, yaitu dimana pendidikan terbesar masyatakat hanya tingkat SD-SMA yaitu sebesar $87,05 \%$. Tidak tamat sekolah sebesar 9,56\%, sedangkan selebihnya sebesar $3,39 \%$ adalah penduduk yang dapat menempuh pendidikan hingga perguruan tinggi.

Dengan demikian dapat dikatakan bahwa tingkat pendidikan masyarakat di dua desa kecamatan Karangploso relatif baik.Melalui pembinaan yang intensif, sumber daya manusia di kedua desa tersebut dapat didorong untuk terlibat aktif dalam pembentukan desa wisata dan pada akhirnya juga berdampak pada peningkatan peluang usaha di desanya masing-masing.

\section{Motivasi Kuat Dari Masyarakat}

Berdasarkan hasil wawancara dan pengamatan yang dilakukan oleh peneliti menunjukkan bahwa rata-rata masyarakat di desa Donowarih dan desa Tawangargo tidak mengetahui tentang konsep desa wisata.Selain itu juga masyarakat di kedua desa belum mengetahui kalau sudah ada rencana pembentukan desa wisata di desanya masing-masing.

Setelah dilakukan diskusi lebih lanjut dengan para tokoh masyarakat, akhirnya diketahui bahwa sosialisasi tentang rencana pembentukan desa wisata masih kurang optimal.Hal ini disebabkan karena sejak tahun 2007 belum ada lagi kejelasan tentang tindaklanjut pembentukan desa wisata di desa Donowarih dan desa Tawangargo.

\section{Dukungan Sarana dan Prasarana}

Selain obyek wisata, faktor yang sangat penting dalam pembentukan desa wisata adalah ketersediaan dan dukungan sarana-prasarana.Diketahu bahwa kecamatan Karangploso telah memiliki sarana dan prasarana meskipun dalam jumlah yang terbatas. Yaitu Kantor Pos hanya satu yang terletak di pusat kota kecamatan, demikian pula puskesmas dan rumah sakit hanya terdapat satu buah di kecamatan Karangploso. Dengan demikian, sarana dan prasarana yang ada tersebut perlu untuk ditingkatkan dan dikembangkan karena merupakan faktor penting dalam upaya untuk mewujudkan desa wisata.

\section{Fasilitas Pendukung Kegiatan Wisata}

Fasilitas umum ini pada dasarnya bukan semata-mata untuk kegiatan wisata saja, tetapi juga membantu dalam memperlancar keseluruhan kegiatan wisata.Secara umumketersediaan fasilitas pendukung cukup memadai, antara lain keberadaan restouran/rumah makan sebesar 35 buah, lapangan olahraga sebanyak 19 buah, pangkalan ojek dan terminal bus masing=masing 17 dan 2 buah. Keberadaan tempat ibadah, yaitu Masjid dan Gereja masing-masing sebesar 90 dan 3 buah. Hal ini sesuai dengan masyarakat pemeluk agamanya.Sedangkan untuk sarana telekomunikai warung telekomunikasi (wartel) sebanyak 9 buah. 


\section{Kelembagaan Desa Wisata}

Keberadaan lembaga desa wisata sangat diperlukan sebagai media untuk dapat menampung, mempromosikan, mengatur serta mengelola keseluruhan kegiatan maupun berbagai kepentingan yang ada.Akan tetapi kelembagaan desa wisata di desa Tawangargo dan desa Donowarih belum terbentuk.Hal ini disebabkan karena menunggu kejelasan dari instansi pemerintah terkait, yaitu Dinas Kebudayaan dan Pariwisata maupun Pemerintah Kabupaten Malang.Berdasarkan informasi yang dilakukan peneliti terhadap perangkat desa, secara umum masing-masing siap untuk membentuk lembaga yang mengelola desa wisata dengan konsep yang partisipatif dan transparan.

\section{Ketersediaan Lahan/Area}

Ketersediaan lahan/area akan memungkinkan untuk dibangunnya berbagai tempat pendukung wisata, antara lain hotel, homestay, rest area, danberbagai wahana rekreasi. Dengan luas wilayah 5.957.898 Ha, dengan wilayah pemukiman sebesar $885.419 \mathrm{Ha}$, atau sebesar 14,86\%. Hal ini menunjukkan bahwa tingkat kepadatan penduduknya masih sangat rendah dan memungkinkan untuk pengembangan berbagai sarana dan fasilitas pendukung pariwisata.

\section{Potensi Pariwisata Eksternal}

Potensi pariwisata eksternal yang dimiliki kecamatan Karangploso adalah letak geografisnya yang sangat strategis.Letak strategis tersebut disebabkan karena kecamatan Karangploso sebagai jalur strategis pariwisata. Para wisatawan yang berasal dari kota Surabaya, Sidoarjo, Bali dan sekitarnya yang hendak bertamasya di Malang Raya, tentu mendahulukan pilihannya ke Kota Batu.

Kecamatan Karangploso memperoleh dampak postif dari keramaian arus wisata yang berasal daru luar kabupaten Malang. Jalur pintas yang menghubungkan Kecamatan Singosari, sebagai pintu masuk wisatawan, dengan Kota Batu melalui kecamatan Karangploso berjarak lebih dekat jika dibandingkan dengan apabila para wisatawan menempuh perjalanan melalui jalur utama kota Malang. Dengan demikian bisa dipastikan bahwa hampir seluruh wisatawan yang hendak berwisata ke Kota Batu akan memilih jalur alternatif (by-pass) yang melewati Kecamatan Karangploso.

\section{Penyusunan Strategi Pembentukan Desa Wisata di Kecamatan Karangploso}

Berdasarkan analisis SWOT di atas, akhirnya dapat ditarik sebuah strategi pembangunan dan pengembangan desa wisata yang berbasis pada kondisi internal (kelemahan dan kelebihan) dan kondisi eksternal (peluang dan tantangan) kecamatan Karangploso kabupaten Malang. 
Tabel 1

Rumusan Strategi Komponen Utama Akses

\begin{tabular}{|c|c|}
\hline Kriteria & Rencana Strategis \\
\hline $\begin{array}{l}\text { Potensi Produk } \\
\text { /daya tarik } \\
\text { wisata }\end{array}$ & $\begin{array}{l}\text { - Pembangunan dan pengembangan konsep desa wisata yang "berbeda” } \\
\text { dengan yang sudah ada. } \\
\text { - Konsep pengembangan obyek wisata berbasis pada potensi } \\
\text { agro/hortikultura yang merupakan komoditas unggulan warga lokal } \\
\text { (jagung manis, sawi daging dll) } \\
\text { - Mengangkat dan mengembangkan seni budaya tradisi lokal } \\
\text { (kudalumping, pencaksilat, hadrah, bari'an) menjadi icon yang unik } \\
\text { dan khas bagi wisatawan } \\
\text { - Pengembangan desa wisata secara partisipatif dengan melibatkan } \\
\text { seluruh stakeholder, hal ini berpijak dari karakteristik masyarakat } \\
\text { yang ramah dan inklusif }\end{array}$ \\
\hline $\begin{array}{l}\text { Dukungan } \\
\text { SDM }\end{array}$ & $\begin{array}{l}\text { - Pendidikan dan pelatihan tentang desa wisata, khususnya kepada } \\
\text { warga yang berada di sekitar obyek wisata } \\
\text { - Pembinaan intensif kepada petani/UKM lokal tentang budidaya } \\
\text { agro/hortikultura dan pengolahan pasca panen agar memiliki daya } \\
\text { saing } \\
\text { - Kursus/pelatihan kewirausahaan berbasis pariwisata kepada penduduk } \\
\text { usia produktif dan putus sekolah agar dapat mengembangkan } \\
\text { kerajinan lokal, souvenir, dll }\end{array}$ \\
\hline $\begin{array}{l}\text { Motivasi } \\
\text { Masyarakat }\end{array}$ & $\begin{array}{l}\text { - Membentuk komunitas/paguyuban desa wisata pada simpul-simpul } \\
\text { yang concern terhadap pembentukan desa wisata. } \\
\text { - Pembentukan Lembaga desa wisata } \\
\text { - Lembaga desa wisata aktif memberikan sosialisasi kepada masyarakt } \\
\text { tentang peta potensi eco-tourism kepada masyarakat melalui brosur } \\
\text { dan forum } 2 \text { warga dan radio lokal sekaligus sebagai tourism } \\
\text { education. }\end{array}$ \\
\hline $\begin{array}{l}\text { Sarana dan } \\
\text { Prasarana }\end{array}$ & $\begin{array}{l}\text { - Perencanaan dan pembangunan sarana \& prasarana yang disesuaikan } \\
\text { dengan konsep dan rencana strategis desa wisata (koordinasi lembaga } \\
\text { ds wisata,Disbudpar dan Pemkab Malang) } \\
\text { - Lembaga pengelola desa wisata berkoordinasi dengan simpul-simpul } \\
\text { komunitas desa wisata secara swadaya membangun sarana-prasarana } \\
\text { tradisional yang unik (halte gubug, kompleks/lapak pedagang kaki } \\
\text { lima dll) } \\
\text { - Memprioritaskan pembangunan infrastruktur jalan untuk } \\
\text { memperlancar akses bagi wisatawan menuju ke desa wisata }\end{array}$ \\
\hline $\begin{array}{l}\text { Fasilitas } \\
\text { Pendukung } \\
\text { Kegiatan } \\
\text { Wisata } \\
\end{array}$ & $\begin{array}{l}\text { - Mengoptimalkan peran Pusat Informasi Desa Wisata yang } \\
\text { bekerjasama dengan biro perjalanan lokal dan tenaga guide } \\
\text { - Perencanaan dan pembangunan fasilitas pendukung keg wisata } \\
\text { (koordinasi lembaga ds wisata, Disbudpar dan Pemkab Malang) }\end{array}$ \\
\hline
\end{tabular}




\begin{tabular}{|l|l|}
\hline & $\begin{array}{l}\text { - Lembaga pengelola desa wisata berkoordinasi dengan simpul-simpul } \\
\text { komunitas desa wisata secara swadaya membangun fasilitas } \\
\text { pendukung keg wisata tradisional yang unik (dokar/bendi, becak hias, } \\
\text { dll) }\end{array}$ \\
\hline $\begin{array}{l}\text { Kelembagaan } \\
\text { Desa Wisata }\end{array}$ & $\begin{array}{l}\text { - Pembentukan lembaga desa wisata sesuai dengan Konsep Disbudpar } \\
\text { Kab Malang tanpa mengabaikan aspirasi dan karakteristik lokal } \\
\text { - Peningkatan kapasitas lembaga desa wisata (institutional building) } \\
\text { melalui pelatihan2 dan studi banding }\end{array}$ \\
\hline $\begin{array}{l}\text { Ketersediaan } \\
\text { Lahan/Area }\end{array}$ & $\begin{array}{l}\text { Membuat perencanaan pemanfaatan ruang/ lahan (spatial) dalam } \\
\text { rangka pembangunan desa wisata yang ramah lingkungan dan tidak } \\
\text { bertentangan dengan Perda RTRW Kab Malang } \\
\text { - Pembangunan/pemanfaatan lahan mempertimbangkan aspek } \\
\text { nilai/norma sosial dan estetika. }\end{array}$ \\
\hline
\end{tabular}

Rencana Strategis di atas merupakan rumusan rencana yang ditarik secara logis berdasarkan kondisi internal (kekuatan, kelemahan) dan kondisi eksternal (peluang dan tantangan) yang dimiliki oleh desa Tawangargo dan desa Donowarih kecamatan Karangploso Kabupaten Malang.Dengan demikian dapat dijadikan dasar dalam perumusan kebijakan dan program kerja dalam rangka pembentukan desa wisata di kecamatan Karangploso.

\section{Model Desa Wisata Kecamatan Karangploso}

Model desa wisata sebagaimana dimaksud dalam penelitian ini adalah sebuah rancangan konsep dan desain sebuah desa wisata yang bertumpu pada potensi lokal yang dikelola sedemikian rupa sehingga memiliki daya tarik yang unik dan khas bagi wisatawan lokal, nasional maupun internasional.Terkait dengan skema pengembangan obyek wisata sebagaimana maka dibuat model klaster pengembangan desa wisata Karangploso sebagai berikut:

\section{Gambar 1}

Klaster Pengembangan Desa Wisata Karangploso

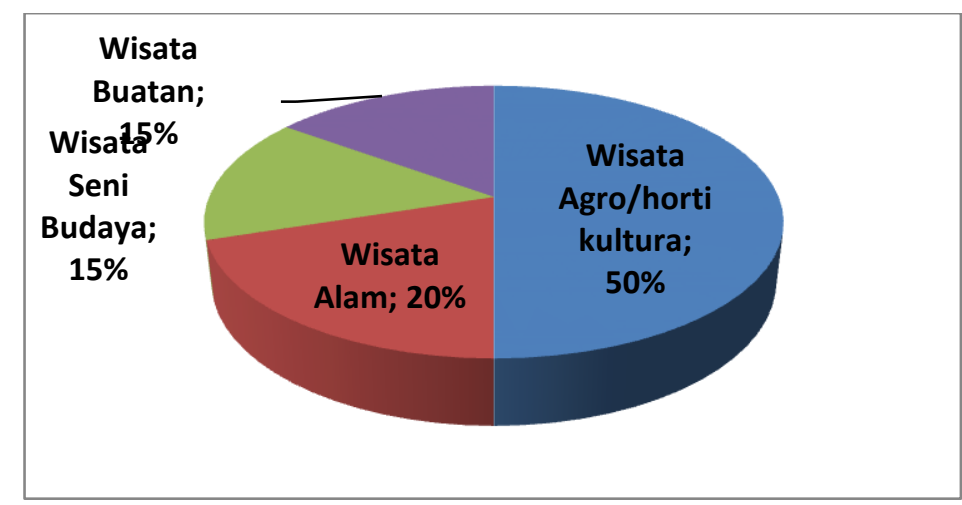

Sedangkan skema lembaga desa wisata secara umum skema/struktur organisasinya menyesuaikan dengan konsep lembaga desa wisata Disbudpar Kabupaten Malang, tetapi dilakukan beberapa penyesuaian. 
Gambar 2

Skema Model Pengembngan Desa Wisata Kec.Karangploso

Dengantema“'Desa wisata berperspektif go green yang unik, khas dan sehat yang berbasis pada keunggulan hortikultura".

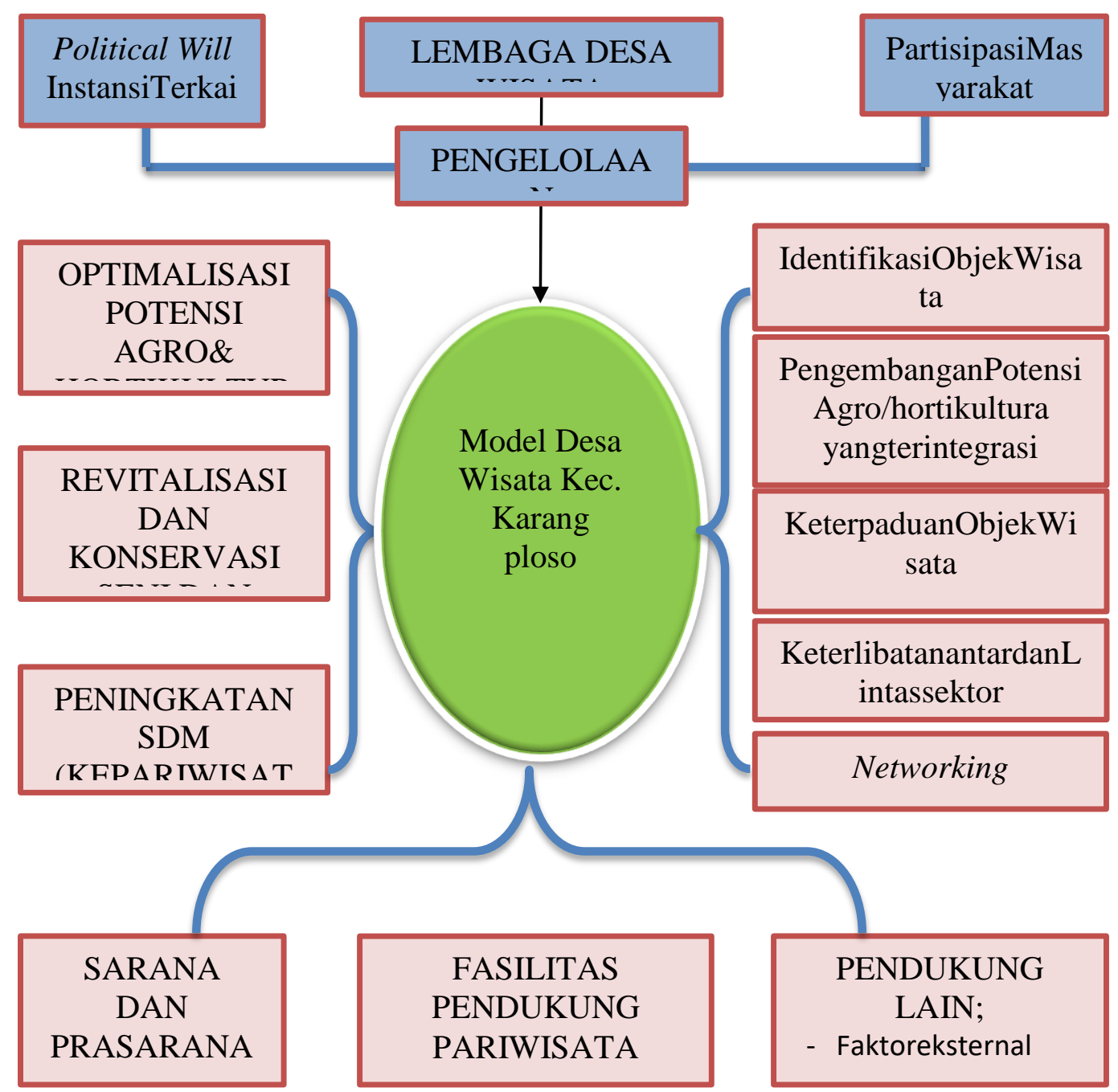

Berdasakan skema pembentukan dan pengembangan desa wisata Kecamatan karangploso bahwa peranan political will dalam upaya mengembangkan pariwisata Kabupaten Malang sangat penting karena sebagai 
otoritas pemerintahan Kabupaten Malang beserta instansi terkait. Sudah tentu hal ini harus didukung oleh peran serta masyarakat dalam membuka usaha-usaha yang berkaitan dengan kepariwisataan. Pihak pemerintah kabupaten mempunyai kewenangan dalam hal landasan hukum dan kebijakan pariwisataserta di sisi lain support/dukungan masyarakat merupakan modal dan pijakan yang sangat besar bagi Lembaga Desa Wisata untuk melakukan pengelolaan berdasarkan aspekaspek penting desa wisata.

Tahapan penting yang perlu dilakukan sesuai dengan skema di atas adalah; (1) optimalisasi potensi agro dan hortikultura, (2) revitalisasi dan konservasi seni dan budaya, (3) peningkatan SDM masyarakat secara umum, khususnya yang berhubungan dengan kepariwisataan. Kerjasama (networking) pada skema tersebut akan menjadi pendorong bagi dilakukannya percepatan (acceleration) bagi pembangunan desa wisata. Kerjasama dapat dilakukan dengan berbagai pihak, baik pemerintah maupun swasta.Sedangkan aspek penting lain yang tidak dapat dipisahkan yaitu adanya daya dukungan dari; ketersediaan sarana dan prasarana, fasilitas pendukung pariwisata serta faktor pendukung lain. Sarana dan prasarana harus dilakukan pembenahan yang bersifat tourist friendly, serta fasilitas pendukung wisata yang spesifik, unik dan sesuai dengan model/tema desa wisata yang dikembangkan..

\section{PENUTUP}

\section{Kesimpulan}

Kesimpulan kajian desa wisata (village tourism) di Kecamatan Karangploso Kabupaten Malang Jawa Timur tahun 2011 adalah sebagai berikut ;

1. Kecamatan Karangploso memiliki potensi internal dan eksternal pariwisata yang dapat dikembangkan menjadi desa wisata. Analisis potensi berdasarkan aspek atau kriteria sebagaimana konsep desa wisata Disbudpar Kabupaten Malang menunjukkan bahwa dari tujuh aspek, hanya aspek kesiapan SDM masyarakat dan aspek fasilitas pendukung pariwisata yang masih perlu ditingkatkan, sedangkan kelima aspek yang lain yaitu; daya tarik wisata, motivasi masyarakat, sarana dan prasarana, kelembagan dan ketersediaan lahan secara umum telah memadai untuk dikembangkan menjadi desa wisata.

2. Strategi pembentukan desa wisata di kecamatan Karangploso dengan menyajikan obyek wisata yang "berbeda" dibandingkan dengan obyek-obyek desa wisata yang telah ada di lingkup Malang Raya (Kota Batu, Kab Malang dan Kota Malang)

3. Berdasarkan analisis tentang potensi internal dan eksternal kecamatan Karangploso kabupaten Malang, maka model desa wisata yang sesuai untuk dikembangkan adalah dengan konsep/tema "Desa wisata berperspektif go green yang unik, khas dan sehat yang berbasis pada keunggulan hortikultura". 


\section{REFERENSI}

Craig-Smith, Stephen dan French, Christine, (1994): Learning to Live with Tourism,Longman, Melbourne.

DinasKebudayaandanPariwisataKabupaten

Malang.

2006. KonsepPengembanganDesaWisata. Malang.

Edward Inskeep, 2009. Tourism Planning An Integrated and Sustainable Development Approach,

French, Christine N, Craig-Smith, Stephen J., Collier, Alan, (1995): Principles of Tourism, Longman, Melbourne.

Gartner, William C., (1996): Tourism Development (Principles, Processes, and Policies), Van Nostrand Reinhold, New York.

Greene, William H., 2000. Econometric Analysis. New Jersey: Prentice-Hall.

Gunn, Clare A., (2002): Tourism Planning (Basisc, Concepts, Cases), Routledge, New York.

Gujarati, Damodar, 2003. EkonometrikaDasar. Jakarta: Erlangga.

Herbert, David T., (1995): Heritage Places, Leisure and Tourism, 120 dalam Herbert, David T., Heritage, Tourism, and Society, 228 p., Pinter, Great Britain.

Moleong, Lexy Johannes. 2002. MetodologiPenelitianKualitatif. PT. RemajaRosdakarya; Bandung.

Nuryanti, Wiendu. 1993. Concept, Perspective and Challenges, makalahbagiandariLaporanKonferensiInternasionalmengenaiPariwis ataBudaya.GadjahMada University Press; Yogyakarta.

Seaton, A.V., (1996): The Marketing Concept in Tourism, 3-27 dalam Seaton, A.V. dan Bennett, M.M., Marketing Tourism Products, 540 p., International Thomson Business Press, London.

Strauss, Anselm da Juliet Corbin. 2003. Terjemahan. Dasar-dasar Penelitian Kualitatif; Tata Langkah dan Teknik-teknik Teorisasi Data.Pustaka Pelajar; Yogyakarta.

UNDP dan WTO. 1981. Tourism Development Plan for Nusa Tenggara, Indonesia. World Tourism Organization press;Madrid.

UNDP, 1990.Human Development Report 1990. New York: Oxford University Press. 
,Undang-Undang No. 10 Tahun 2009 tentangKepariwisataan

, 1995.Human Development Report 1995. New York: Oxford University Press.

, 2004.Human Development Report 2004. New York

, 2007.Human Development Report 2007/2008. New York: Palgrave Macmillan.

,(2003): Studi Analisis Potensi Pasar Wisatawan Nusantara (Studi Kasus: Bali), LaporanAkhir, Kementerian Kebudayaan dan Pariwisata, Jakarta.

, Definition of Tourism, www.world-tourism.org, diunduhtanggal 17 Agustus 2010. 